Original Research Paper

\title{
Scientific Literacy-Based Chemical Teaching Materials Design of Chemical Solution Materials on Sea Pollution Context
}

\author{
Nurul Asikin ${ }^{*}$, Inelda Yulita ${ }^{1}$ \\ ${ }^{1}$ Faculty of Teacher Training and Education, Universitas Maritim Raja Ali Haji, Tanjungpinang, Indonesia
}

Article history

Received: February $20^{\text {th }} 2019$

Revised: June $20^{\text {th }} 2019$

Accepted: July $10^{\text {th }} 2019$

*Nurul Asikin, Universitas

Maritim Raja Ali Haji,

Tanjungpinang, Indonesia;

Email:

nurul_asikin@umrah.ac.id

\begin{abstract}
The science teaching materials needed today are teaching materials that can make students literate in science. One way is to develop teaching materials based on scientific literacy. To produce good teaching materials, certain designs are needed to achieve learning goals and can improve students' scientific literacy. Students who have studied chemistry should be able to analyze natural phenomena in scientific chemistry, one of which is marine pollution. This research was conducted to design high school chemistry teaching materials in connecting the context of sea pollution with chemical solution material. The method of this research is descriptive qualitative which refers to the Model of Educational Reconstruction (MER). The instruments used were standard competence validation sheets, text analysis sheets, and teaching material validation sheets. The results showed: a) The results of the indicator standard competence validation and learning objectives cognitive and attitude aspects, the results of text analysis and the results of the validation of teaching materials, all obtained valid categories, with the average value of each CVI was $0.91 ; 0.93 ; 0.94$; and 0.95 , b) The design of teaching materials include the contact stage, the curriculum stage, the elaboration stage, the decision-making stage, and the Nexus stage.
\end{abstract}

Keywords: Design of teaching materials; scientific literacy; sea pollution; chemical solution

\section{Introduction}

Teaching material is a set teaching material that is arranged systematically, displaying a complete figure of competencies to be delivered to students in learning activities. Good teaching materials are teaching materials that can support students' ability to understand science, communicate and apply it as scientific literacy. The development of teaching materials has been carried out by the teachers, but not all of the teaching materials can support the achievement of students' scientific literacy. This can be proven from the measurements results of international student literacy of PISA. The Programme for International Student Assessment that has been developed by several developing countries in the world that are incorporated in The Organisation for Economic Cooperation and Development (OECD) based in Paris, France.

This program is a three-year program starting in 2000, continued in 2003, 2006, 2009 and 2012. The results of the PISA study show that mastery of the scientific literacy of Indonesian students is still at a low level. No Indonesian students have been able to reach levels 5 and 6 , namely the ability to identify scientific components of various complex life situations, applying scientific concepts and knowledge of science, comparing, selecting and evaluating according to scientific evidence to respond to a life situation. According to the scale applied by PISA, Indonesian students are able to reach low levels, namely at the ability to explain simple concepts (OEDC, 2013).

PISA as a program in assessing scientific literacy students divide scientific literacy into three domains in their measurement, namely science content, science process, and science application context (Schwartz, et al, 2006) add aspects of attitude to the domain of scientific literacy. Based on this, the assessment of scientific literacy in PISA not only measures the level of understanding of scientific knowledge, but also the understanding of various aspects of the scientific process, as well as the ability to apply science and science processes to real situations faced by students (Firman, 2007). The contextual aspect is a real situation that is specifically raised in learning, not only from the material learned at school (Toharudin, et al, 2011). This aspect refers to natural phenomena and 
changes made by nature through human activities. The context of scientific literacy in PISA is more about everyday life than class or laboratory. Whereas in the process aspect, identification of scientific questions is carried out, explaining scientific phenomena and using scientific evidence (OECD, 2013). This aspect requires demonstrations carried out by students that will bring up cognitive knowledge skills as well as student attitudes and motivations.

Science literacy-based learning is learning that is based on developing the ability of scientific knowledge in various joints of life, finding solutions to problems, making decisions, and improving quality of life (Toharudin, et al, 2011). The low scientific literacy of Indonesian students is suspected because the curriculum, learning process, and assessment carried out do not support the achievement of scientific literacy (Firman, 2007; Jufri, et al.,2019). All three are still focused on discussing rote content, and forgetting the process of thinking skills as the context of science applications. The trend that occurs in science learning today is more emphasis on understanding material concepts, without connecting them with life functions such as relations to the environment, health, and society (Asikin, et al, 2016). This causes the learning of science, especially chemistry, to be less favored by students and learning is less relevant in the context of everyday life (Holbrook, 2005).

Toharudin, et al (2011) stated the importance of the existence of teaching materials in supporting learning success. Teaching materials can help connect experience with student knowledge. Learning science should not be separated from everyday life. One alternative solution to this problem is to develop teaching materials that are able to answer the challenges for students, namely teaching materials that discuss current phenomena and issues and relate them to lesson content. One phenomenon that is close to students and contains chemical content is the phenomenon of seawater pollution.

The role of teaching materials is very important because the teacher's function can be played by the teaching material. Therefore, teaching materials must be made in a form that is in accordance with the needs and characteristics of the teaching material to be presented. According to Anwar (2010), so that teaching materials have a form that fits the needs and characteristics of teaching material, then there are four stages carried out in making teaching materials, including Selection Process, Compilation Process, Structuring Process, Characterization Process, and Reduction Process.
According to McComas (2002) knowledge based on philosophy and history of science will be more helpful in achieving scientific literacy. This principle invites students to think like a scientist. By using teaching materials that apply the phenomenon of seawater pollution in one of the contents of chemistry subjects in senior high school, it is expected that there will be an increase in students' understanding of chemical solution material.

Based on this, the authors conducted a study on the construction of teaching materials that use the context of marine pollution in chemical solution material to improve the scientific literacy skills of senior high school students.

\section{Method}

The method used in this study is descriptive qualitative using the Model of Educational Reconstruction (MER) which is limited to the stage of clarification and analysis of the structure of the content, and the investigation of the pre-conception of students. This model is designed to provide a basic framework for the structure of learning content taken from the structure of elements science content. The structure of science content is not taken directly but is taken from basic ideas through an element process. These basic ideas are then constructed according to cognitive and affective learning goals (Duit et al, 2012).

The research design is elaborated in the following steps: 1) Stage of Literature Analysis. The stage of the Pre-conception Study of Students on the concept of chemistry in senior high school, maritime context and their Relationship. 2) Stage of Scientific Perspective Study on the concept of chemistry in senior high school, maritime context and their relations. 3) The Original Text Clarification Stage. 4) Text Sequence Map Preparation Stage.

Source of data in the study come from the results of instrument validation conducted by five experts. The validated instrument is a validation sheet of indicator suitability and learning objectives in cognitive and affective aspects, concept analysis validation sheets and teaching material validation sheets. The acquisition of validation results is then calculated using CVR (Content Validity Ratio).

Content Validity Ratio (CVR) is used to measure validity index based on quantitative content validation. Validation of content with regard to validity of a measuring instrument is seen in terms of content of subject matter involving experts to assess. The CVR formula is: 


$$
\mathrm{CVR}=\frac{n e-N / 2}{N / 2}
$$

Information:

$n e$ : number of experts who agree

$\mathrm{N}$ : the number of all experts who validate

(Alahyari et al, 2011).

The characteristics of CVR assessment are as follows: 1) When less than half the expert's answer "yes", the CVR value will be negative. 2) When half the panelists answer "yes" and the other half answer "no" then the acquisition of the CVR value is 0. 3) When all panelists answer "yes", the acquisition of CVR value is 1 . When the number of panelists who answer "yes" is more than half, the CVR value ranges from $0-0.99$.

Wilson et al (2012) in the analysis of the calculation of the value of CVR table obtained a new value for CVR table which is a reference from CVR table Lawshe (1975). For example, for experts totaling seven people, the Lawshe CVR table value at a significant level $(\alpha=0.05)$ is 0.99 . While the calculation of CVR table Wilson, et al (2012) with the number of experts and the same level of significance $(\alpha)$ was obtained at 0.62 . See table 1 .

After identifying sub-questions on the validation sheet using CVR, then CVI (Content Validity Index) is calculated. In simple terms, CVI is the average of the CVR values for sub-questions answered "yes". CVI calculations are obtained using the formula of:

$$
\text { CVI }=\frac{\Sigma \text { CVR }}{\text { Number of sub questions }}
$$

(Alahyari et al, 2011).

Table 1. Critical value for Content Validity Ratio (CVR)

\begin{tabular}{lllll}
\hline \multicolumn{5}{l}{ Significant value for one tailed test } \\
\hline & 0,10 & 0,05 & 0,025 & 0,01 \\
\hline & \multicolumn{5}{l}{ Significant value for two tailed test } \\
\hline $\mathrm{N}$ & 0,20 & 0,10 & 0,05 & 0,02 \\
5 & $\mathbf{0 , 5 7 3}$ & 0,736 & 0,877 & 0,990 \\
6 & 0,523 & 0,672 & 0.800 & 0,990 \\
7 & 0,485 & 0,622 & 0,741 & 0,974 \\
8 & 0,453 & 0,582 & 0,693 & 0,911 \\
\hline
\end{tabular}

The results of CVR and CVI calculations are in the form of a 0-1 number ratio. Whether or not a validated unit depends on achieving a CVR critical value. Based on the CVR critical value table that has been recalculated for five validators $(\alpha=0.10)$ (Wilson et al, 2012), the critical value is 0.573 . This means that only units with a CVR value of $>0.573$ are declared valid, while the other units need repairs.

\section{Result and Discussion}

The results showed that: a) The results of the indicator standard competence validation and learning objectives cognitive and attitude aspects, the results of the text analysis and the results of teaching material validation, all obtained valid categories, with the average CVR value of 0.98 ; $0.90 ; 0.98$; and $0.95, \mathrm{~b})$ The design of teaching materials includes the contact stage, the curiosity stage, the elaboration stage, the decision-making stage, and the Nexus stage.

Research has been carried out by beginning with the literature analysis stage. The analysis was carried out in the form of a review of core competencies and basic competencies in chemistry subjects in high school class $X$, review of the literature on scientific literacy, analysis of maritime contexts, analysis of chemical content, maritime context, and dimensional analysis of scientific literacy (cognitive aspects and attitude aspects) and formulation indicators and learning objectives for cognitive aspects and attitudes based on science literacy and applicable curriculum.

The literature analysis results in the determination of chemical content and maritime context that are appropriate to be integrated as teaching materials that fulfill four aspects of scientific literacy in PISA, namely aspects of context, aspects of knowledge, aspects of competence and aspects of attitude. The context aspect aims to introduce science through the maritime environment, which is about the phenomenon of sea water. While the knowledge aspect is knowledge related to chemistry material in senior high school, namely the nature of chemistry (Depdikbud, 2014). This material is the initial material given to students class $\mathrm{X}$ in senior high school who discuss basic materials such as elements, compounds, mixtures, changes in physics and chemistry, and scientific methods. While aspects of competence and attitudes are integrated in the formulation of learning indicators (Yulita, 2018).

This first stage resulted in the formulation of indicators and learning objectives cognitive aspects and attitudes based on 2013 scientific and curriculum literacy. The indicators of cognitive aspects and attitude aspects that have been formulated were given to experts to be validated. The validator consists of two chemistry lecturers and three chemistry teachers from senior high school. The purpose of validation is to find out whether the indicator is in accordance with the context, content, and PISA competencies. Score from the expert assessment of these indicators and objectives consist of conformity of indicators with 
standard competence, the suitability of indicators with aspects of competence or aspects of PISA 2012 attitude, and suitability of learning objectives with indicators.

Each item will get a CVR value that will determine whether or not each indicator is valid and the learning objectives. CVR values of some items are converted into CVI values in order to obtain the average CVR indicator value and overall learning goals. To determine valid or invalid CVR table prices are used as parameters. CVR tables with 5 panelists were 0.573 . This value is also the same for the CVI table value. If the price of the CVI is greater than the price of the CVI table, then the indicators and learning objectives are valid. Conversely, if the CVI price is smaller than the CVI table price, then the indicator item is invalid. The results of indicator validation and learning objectives cognitive aspects and attitudes can be seen in Tables 2 and Tables 3.

After knowing the CVI value of each indicator item, then calculating the CVI mean value from three indicators and seven learning objectives for cognitive aspects. The average value of CVI for indicators and learning objectives for cognitive aspects is 0.91. It means that the formulation of indicators and learning objectives in the cognitive aspects is valid because the acquisition of the calculated CVI value is greater than the CVI table. The same thing is applied to the indicators of attitude aspects, which are obtained by the average value of CVI for indicators and the learning objectives of the attitude aspect is 0.93 . This means that the formulation of indicators and learning objectives on aspects of attitudes are also valid.

Table 2. CVI Values from Validation Indicators and Learning Objectives Cognitive Aspects

\begin{tabular}{lcc}
\hline Indicator & Learning objectives & CVI \\
\hline $\begin{array}{l}\text { 1. Analyze the concept of solution } \\
\text { to the context of marine pollution }\end{array}$ & $\begin{array}{c}\text { 1.1 Students are able to analyze the concept of solution to the sea } \\
\text { pollution discourse appropriately } \\
\text { 1.2 Students are able to deduce the importance of sea water as the } \\
\text { application of the solution concept correctly. }\end{array}$ \\
$\begin{array}{l}\text { 1.3 Students are able to find pollutant compounds as the application of } \\
\text { the solution concept correctly. }\end{array}$ & $\begin{array}{l}1 \\
\text { 2.1 Students are able to implement the concept of the types of solutions } \\
\text { to the source of marine pollution appropriately }\end{array}$ \\
$\begin{array}{l}\text { 2. Implement the concept of types } \\
\text { of solutions to the phenomenon } \\
\text { of marine pollution }\end{array}$ & $\begin{array}{c}\text { 2.2 Students are able to implement the concept of types of solutions to } \\
\text { the phenomenon of oil spills in seawater appropriately }\end{array}$ \\
$\begin{array}{l}\text { 3. Evaluate the flame test for the } \\
\text { effects caused by marine } \\
\text { pollutants. }\end{array}$ & $\begin{array}{c}\text { Students are able to evaluate precisely the conductivity of } \\
\text { electrolyte solutions that occur due to marine pollution. }\end{array}$ & 0.78 \\
Average of CVI & the canoe as a way to reduce the impact of marine pollution. & 0.78
\end{tabular}

After obtaining indicators and learning objectives cognitive aspects and attitudes that have been valid in the first stage will be a guide to the next research stage, namely the preparation stage of the Text Sequence Map. However, before entering at that stage, the pre-conception study stage of the students and the scientist's perspective on chemical solution content, the sea pollution context, and the relationship between them.
The next step is the clarification of the original text. At this stage, the process of the element of context and content is carried out. The element process aims to find the basic ideas of the structure of scientific content that can be reached by students and take an interesting context structure. There are several sources that are used as references in analyzing content and context qualitatively. The following Table 4 is a textbook used.

Table 3. CVI Values of Indicator Validation and Attitude Aspect Learning Objectives

\begin{tabular}{lcc}
\hline Indicator & Learning objectives & CVI \\
\hline $\begin{array}{l}\text { 1. Demonstrate interest in analyzing the concept } \\
\text { of solution to the context of marine pollution }\end{array}$ & $\begin{array}{c}\text { 1.1 Students show interest in analyzing the concept of } \\
\text { solution to the context of sea pollution. }\end{array}$ \\
$\begin{array}{l}\text { 2. Support the use of factual information in } \\
\text { implementing the concept of types of solutions }\end{array}$ & $\begin{array}{c}\text { 2.1 Students demonstrate their support for the use of factual } \\
\text { information in implementing the concept of types of } \\
\text { to the phenomenon of sea pollution. }\end{array}$ & solutions to the phenomenon of sea pollution. \\
3. Demonstrate concern and support in & 3.1 Students show concern and support in designing flame \\
evaluating flame tests on the effects of & tests for fisherman lighting to reduce the impact of & 0.78 \\
pollutants. & marine pollution. & \\
CVI Average & &
\end{tabular}


From five textbooks above, the first to fourth books are used for the analysis of chemical solution content. These books are chosen because the content of the chemical solution materials is presented more fully and supported by many images that would facilitate understanding of the content. While the fifth and sixth books are used for ocean pollution analysis. The context of sea pollution presented is the result of expert research.

The analysis is grouped into content analysis and context analysis. The analysis is done to find important materials that students should know, then translate into easily understood languages. Not all material in the content and context is taken but only the parts needed by students are selected. So that it is found an association or relationship between chemical solution content and the context of sea pollution. The analysis of the resulting concept is validated by experts with the following results. (Table 5).

Table 4. Textbooks Used in Content Analysis and Context

\begin{tabular}{clll}
\hline No & Book title & Author & Publication Year \\
\hline 1 & Chemistry The Molecular Nature of Matter. & $\begin{array}{l}\text { Jesperson, N. D. Brady. J. E. and } \\
\text { Hyslop. A. }\end{array}$ & 2012 \\
2 & $\begin{array}{l}\text { Chemistry: Principles and Practice, Third } \\
\text { Edition }\end{array}$ & $\begin{array}{l}\text { Reger, D. L. Goode, S. R. and Ball, D. } \\
\text { W. }\end{array}$ & 2010 \\
3 & $\begin{array}{l}\text { Pedoman Mata Pelajaran Kimia pada Kurikulum } \\
\text { Kimia 2013 }\end{array}$ & Depdikbud & 2014 \\
4 & $\begin{array}{l}\text { Pedoman Penilaian Buku Pelajaran Kimia } \\
\text { Sekolah Menengah Atas } \\
5\end{array}$ & $\begin{array}{l}\text { Sea water as an electrolyte } \\
\text { The Chemical and Physical Properties of Marine } \\
\text { Aerosols: An Introduction }\end{array}$ & Millero, F. J. \\
Prospero J. M. & 2004 \\
\end{tabular}

Table 5. Analysis of concepts between chemical solution content and the context of marine pollution

\begin{tabular}{llll}
\hline No & Concept Label & $\begin{array}{l}\text { Number of } \\
\text { Concept }\end{array}$ & CVI \\
\hline 1 & $\begin{array}{l}\text { For Chemical } \\
\text { Solution content }\end{array}$ & 5 & 0.95 \\
2 & $\begin{array}{l}\text { For the context of sea } \\
\text { pollution }\end{array}$ & 9 & 0.93 \\
Average CVI & 0.94 \\
\hline
\end{tabular}

The next stage is the preparation of the Text Sequence Map, which is a description of the sequence map of the teaching material to be constructed. This arrangement is based on the results of students on the context of seawater and the process of element content and context. In this study, the compilation of a text sequence map was carried out using the stages of learning Science and Technology Literacy (STL) adopted from project learning Chemie in Kontext in Nentwig et al (2007) and Holbrook (2005). Learning sequences related to contact, sensitivity, elaboration, decision making, and Nexus. By following the STL learning process, it is hoped that students can develop thought processes and can connect chemicals with the phenomenon of ocean pollution. The following is a sequence of teaching materials that are adjusted to the STL criteria, namely:

\section{Contact Phase}

At the contact, stage students are introduced to seawater and the importance of seawater. This aims to instill the concept that sea water is important for humans and their lives. So that when the concept of sea pollution begins in teaching materials, the sense of caring is getting higher. The discussion on the concept of sea pollution is divided into 3 parts, namely the causes of marine pollution, the impact of marine pollution, and the solution to marine pollution.

The cause of marine pollution is divided into 2 parts, namely pollutants and sources of marine pollution. As students who have understood the concept and compilation of the previous material, students can obtain deeper abilities in discovering these chemicals in finding pollutant competencies that cause sea pollution. While the sources of marine pollution are complete, starting from domestic, industrial and agricultural sources.

Furthermore, the impact of marine pollution is discussed in bioaccumulation and biomagnification. Although it is limited to these two things, it is hoped that students will be able to dig deeper into other impacts that can be caused by marine pollution. Similar to the solutions offered in marine pollution, it is only limited to alternative lighting that can be used by fishermen without using oil which can be a cause of sea pollution. The order of this stage can be seen in the following Figure1: 


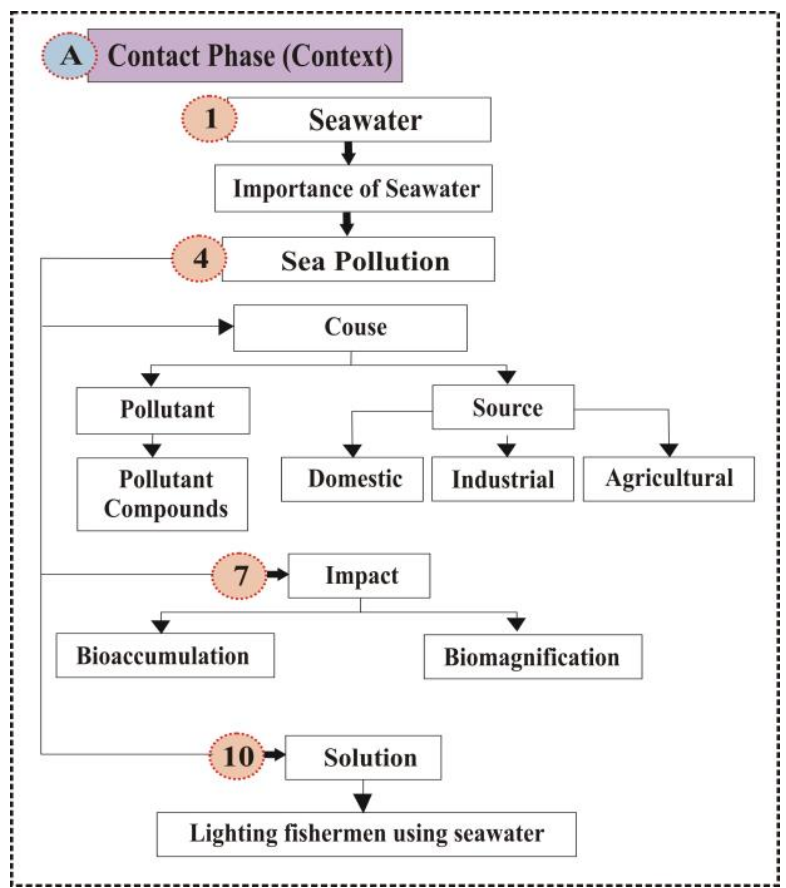

Figure 1. Text sequence map, Contact Phase

\section{Curiosity Phase}

At the curiosity level, instructional materials are designed by presenting questions that can raise students' curiosity. In this teaching material, there are several questions that can lead to student interest and can stimulate students to summarize other questions. The more questions that arise in the minds of students the better they are, because it is an indicator of the increasing curiosity of students.

Curiosity is very necessary to make it easier for students to understand the next material. The questions presented in teaching materials are: 1) Is seawater a salt solution that includes electrolyte solutions? 2) Can marine pollution be categorized as a solution? Is the entry of pollutants into the sea included in the concept of solution or no solution? 3 ) If sea pollution is included in the concept of solution, can pollutants affect the conductivity of the solution? 4) How can seawater be used as lighting for fishermen using the concept of flame test equipment? What are the advantages and disadvantages? 5) Is the chemical solution material being studied useful in understanding the phenomenon of sea pollution?

With these questions, students are expected to be able to think comprehensively, because students are invited to think about past, present and in the future. Questions given are in accordance with the facts that occur in everyday life. With the knowledge they obtain from various sources and explanations at the elaboration stage in the teaching material, students are expected to be able to solve the problem.

\section{Elaboration Phase}

At this stage, exploration is carried out, the formation and consolidation of concepts until the questions at the curiosity stage can be answered. Teaching materials are developed based on indicators and learning objectives cognitive aspects and aspects of attitudes that have been validated. Consolidation of the concept is given by giving an explanation of the concept of chemical solutions and the implementation of these concepts to the phenomenon of sea pollution.

In the elaboration stage, the definition of the solution and the difference between a solution and not solutions are discussed. Next, proceed with the types of solutions based on the scattering power consisting of electrolyte and non-electrolyte solutions. At this stage also discussed the function of the solution and the concept of the flame test. Chemical solution material has the basic competency of skills, namely designing a flame test apparatus and testing solutions whether including electrolyte larvae or not. The concept implanted here is not only about testing a number of solutions, but students are invited to try sea water as a solution. Furthermore, find the influence of a clean ocean with the ocean that has been contaminated with the conductivity of the solution.

At this stage, students are expected to be creative in conducting experimental innovations. The things that are obtained by each student must be different so that in the teaching material a room is provided to describe their findings. The concept of the flame test is expected to stimulate the ability of critical thinking students when using the ocean as a giant electrolyte solution. The order of this stage can be seen in Figure 2 below:

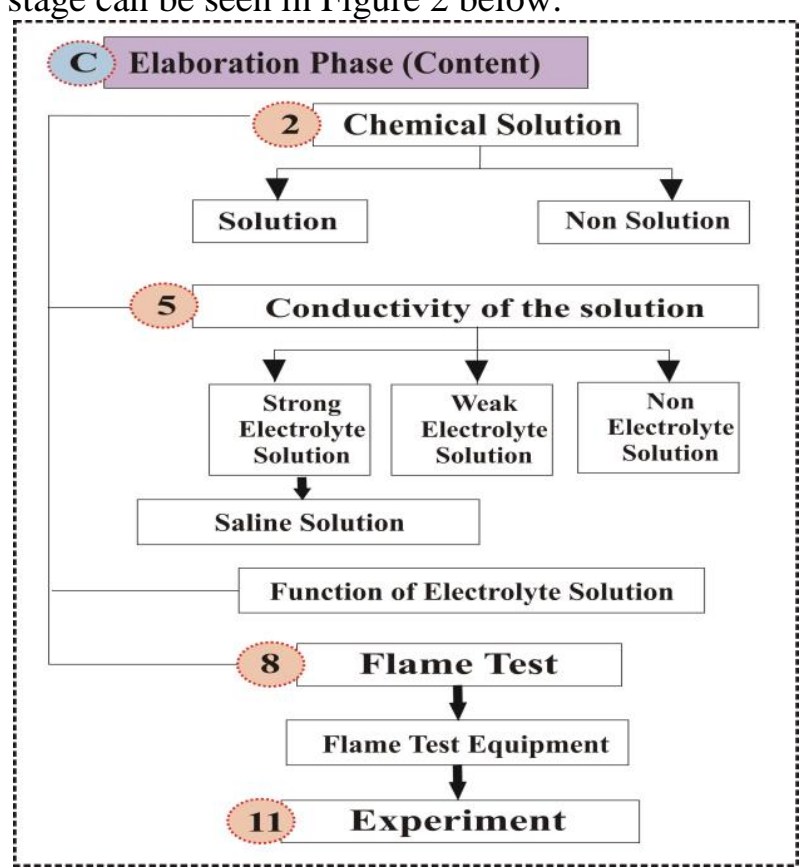

Figure 2. Text sequence map, Elaboration Phase 


\section{Decision Making Phase}

At this stage, students are expected to be able to make decisions from the problems raised at the stage of the curriculum. At this stage students also analyze the situation to make the right decisions, namely the importance of the oceans for human life so that everything related to the sea must be kept clean. At this stage, there was an awareness that what caused marine pollution was humans, while the results of pollution also had an impact on humans, and that which provided a solution to the pollution was also human. This means that humans are the key to everything. So as an academic must be a solution to environmental problems, not the cause of the problem.

\section{Nexus Phase}

At this stage, the extraction process is carried out from the material studied (decontextualization), then applying it to other contexts (recontextualization) (Nentwig, et al, 2007). In the teaching material, the conclusions of the chemical solution material are related to the phenomenon of ocean pollution. Then proceed with giving an overview of other chemical concepts that are also integrated with pollution.

The design of teaching materials is revalidated by experts. Validation is carried out per material concept both content and context so that the CVI results obtained for each stage are then calculated by the average CVI. The results of the validation of teaching materials can be seen in Table 6 below:

Tabel 6 . The results of validating teaching materials

\begin{tabular}{ll}
\hline Stage & CVI value \\
\hline Contact stage & 0,88 \\
Curiosity stage & 1 \\
Elaboration stage & 0,98 \\
Decision making stage & 0,90 \\
Nexus Stage & 1 \\
Average CVI & 0,95 \\
\hline
\end{tabular}

Validation of teaching materials is carried out in 4 categories, namely a) the accuracy and suitability of content and context, b) the suitability of the material with the curriculum (learning objectives), c) the accuracy of illustration images/symbols, and d) eligibility for use by high school students. With the CVI value averaging 0.95 , the instructional materials designed fall into the valid category.

\section{Conclusion}

The results of the indicator standard competence validation and learning objectives cognitive and attitude aspects, the results of text analysis and the results of the validation of teaching materials, all obtained valid categories, with the average value of each CVI being 0.91; 0.93; 0.94; and 0.95 . The design of teaching materials that are able to improve students' scientific literacy includes the contact stage by using the context of sea pollution, the stage of the curriculum, the elaboration stage with chemical solution content, the decision-making stage, and the Nexus stage.

\section{Acknowledgement}

The authors would like to thank of the Ministry of Research, Technology, and Higher Education of Indonesia for their funding support of this research, Research Institute and Community Service of Universitas Maritim Raja Ali Haji, and Editorial Jurnal of Research in Science Education.

\section{References}

Asikin, N., Irawati, M.H., Syamsuri, I. 2016. Pembelajaran Biologi Berpendekatan Saintifik Model Sains Teknologi Masyarakat Untuk Meningkatkan Hasil Belajar Siswa. Jurnal Pedagogi Hayati, 1(1), 1-10.

Depdikbud. 2014. Pedoman Mata Pelajaran Kimia pada Kurikulum Kimia 2013. Jakarta: Depdikbud

Duit, R., Gropengießer, H., Kattmann, U., Komorek, M., Parchmann, I. 2012. The Model of Educational Reconstruction - a Framework for Improving Teaching and Learning Science. In: Jorde D., Dillon J. (eds) Science Education Research and Practice in Europe. Cultural Perpectives in Science Education, 5. SensePublishers, Rotterdam

Firman, H. 2007. Laporan Hasil Analisis Literasi Sains berdasarkan hasil PISA Nasional tahun 2006. Puspendik

Holbrook, J. 2005. Making Chemistry Teaching Relevant. Chemical Education International. 6(1), 1-12.

Ismunandar, P. A. 2004. Pedoman Penilaian Buku Pelajaran Kimia Sekolah Menengah Atas. Jakarta: Pusbuk Depdiknas

Jesperson, N. D, and Brady, J. E. 2012. Chemistry The Molecular Nature of Matter. United States of America: John Wiley and Sons, Inc. 
Jufri, A.W., Ramdani, A., Jamaluddin., Azizah, A. 2019. Development of Scientific Literacy and Pedagogical Content Knowledge (PCK) of Prospective Science Teachers through Lesson Study-Based Courses. Jurnal Penelitian Pendidikan IPA (JPPIPA), 5(2), 179-184.

Millero, F. J. 2002. Sea water as an electrolyte. New York: Springer-Verlag Berlin Heidelberg

McComas. 2002. The Nature of Science in Science Education Rationales and Strategies. United States of America: Kluwer Academic.

Nentwig, P. M., Reinhard, D., Ilka, P., Bernd, D., Cornelia, G. 2007. Chemie im Kontext: Situating Learning in Relevant Contexts while Systematically Developing Basic Chemical Concepts. Journal of Chemical Education. 82(9). 1439. DOI. https://doi.org/10.1021/ed084p1439

OECD. (2013). PISA 2012 Assessment and Analytical Framework: Mathematic, Reading, Science, Problem Solving and Financial Literacy. OECD Publishing. DOI. http://dx.doi.org/10.1787/9789264190511en

Reger, D. L., Goode, S. R., and Ball, D. W. 2010. Chemistry: Principles and Practice, Third Edition: Canada: Mary Finch

Schwartz, Y., Ben-Zvi, R., and Hofdtein, A. 2006. The use of scientific literacy taxonomy for assessing the development of chemical literacy among high-school students. The royal society of chemistry. Chemistry education research and practice, 7(4), 203225.

Toharudin, U., Hendrawati, S., dan Rustaman, A. 2011. Membangun Literasi Sains Siswa. Bandung: Humaniora.

Yulita, I. 2018. Analisis Prekonsepsi Siswa Terhadap Kemampuan Menghubungkan Konteks Air Laut Dengan Konten Hakikat Ilmu Kimia Kelas X SMA. Jurnal Pendidikan Sains (JPS), 6(1), 64-72. 